\title{
EXPLORING THOUGHTS OF INDONESIAN TERRORISTS ON I'DAD AND JIHAD: PSYCHOLOGICAL PERSPECTIVES
}

\author{
Gazi \\ Syarif Hidayatullah State Islamic University (UIN) Jakarta \\ gazi@uinjkt.ac.id
}

\begin{abstract}
Idad and jihad are some of basic concepts that radical Islamic groups and terrorists including in Indonesia use to express their strategies in dealing with perceived threat toward outgroups. This study aims to examine how those concepts become basic arguments in doing military training and act of terror that violate law of radicalism and terrorism in Indonesia. This study uses qualitative method with interview and documents review including those from social media in particular youtube as tools of data collecting. The data in particular that taken from interview and direct statements of terrorists and radicals in youtube are analyzed by qualitative analysis technique and psychological perspective are used to explain why do they prefer to understand such that way. The study concludes that idad and jihad were misunderstood because of their simple understanding on those two concepts.
\end{abstract}

Keywords: Thought, idad, jihad, psychological perspectives

\section{Introduction}

Act of terror has been global threat that all nations and states concern about it. All people from all over the world assume and believe that terror is enemy of the civilization and humanity that must be opposed and eliminated (Borum, 2008). In order to find some ways to take action against terrorism and radicalism, some experts in social sciences including psychologists devoted their energies and thoughts in order to find how to deal with radicalism and terrorism (Smelser \& Mitchel, 2002). Indonesia as a state with many cases of terrorism inevitably also has to use all his capabilities and energies to take some strategies and strategic steps to eradicate radicalism and terrorism.

The problem is that they focused on looking for root causes that related to economic and political factors and do not try to view other factors such as psychological factors. In this term, it must be known that radicalism and terrorism are about people behavior that consists of thought, feeling and action. It can be said that talking about radicalism and terrorism is not enough without looking at psychological dimensions of terrorists (Victoroff \& Kruglanski, 2009). This article is trying to see this issue from psychological perspectives and particularly from the terrorists and radicals point of view.

In my opinion, to see radicalism and terrorism from psychological perspectives and terrorist point of view is something unique and interesting since many experts overlooked it and more focus to political and sociological perspectives. Furthermore, psychological perspectives and terrorists point of view that used in this article will be combined with Islamic studies perspectives in particular fiqh al-jihad. Last but not least, choosing these perspectives will complement other perspectives that has been taken for long times by huge of experts in radicalism and terrorism studies. More specifically, those perspectives would give people something pivotal things related to what they think and feel about social world specifically that related to perceived threat from out-groups (Moghaddam, 2006). 
This article will discuss comparison and difference between what terrorists and radicals understanding about idad (preparation for jihad) and jihad it's self in on hand, and what Muslim clerics interpret about those two main concepts in fiqh al-jihad.

According to psychological perspectives in general, thought is son of behavior. In other words, what you have been doing is description of what you are thinking. In term of relation between thinking and action, most classic studies in psychology revealed that attitude predicted behavior although other studies also revealed the contrary (Baumeister \& Finkel, 2010). In this context, some researchers strongly believed that terrorist understanding and belief about religious texts would influence their actions including in social relation with out-groups or what has been known in social psychology as intergroup relation matters.

Some studies suggested that radicalism and terrorism was not only about personal behavior or group behavior but they also about intergroup behavior (Postmes \& Jetten, 2006) (Borum, 2008). One of many explanations about radicalism and terrorism was that perceived threats could motivate someone to act in order to protect the group from at least negative perceptions of other groups (Moghaddam, 2006). Based on my experiences in interaction with terrorists' inmates I found that their cognition was full of perceived threats, prejudice toward out-groups in particular those have been assumed as enemies of Islam such as Christians, Buddhists or even polices and government. These out-groups used to be labelled as thaghut (Gazi, 2016).

Therefore it is pivotal thing to know what terrorist think about idad and jihad as strategies in standing up Islam and Muslims according to their perceptions. And the most important thing is why they think about it or in other words what motivate them to act terror and prejudice on behalf of defending Islam and Muslims?

Based on above explanation, some questions was constructed to be answered in this study, there were: First, what do respondents understand with idad and jihad? Second, is respondents understanding about idad and jihad in line with Muslim scholars in general? Third, why do respondents choosed idad and jihad in fighting for Islam and dealing with perceived threat toward Muslims and Islam?

These questions will be answered through qualitative study that has been conducted for long times. Therefore, this study can be said as longitudinal study about radicalism and terrorism in Indonesia. Studying about idad and jihad in psychological perspective certainly used qualitative method.

It is because qualitative method is strongly suit terrorism theme. 25 convicted and former terrorists were chosen to be respondent and five of them have decided to leave terrorism. Data were collected through interview and documents review in particular those from social media such as YouTube and analyzed with qualitative technique analysis mainly thematic analysis.

The interviews was done in some cities such as Jakarta, Depok, Pekanbaru, Makasar, Surabaya, Bogor, and Tangerang both in jail and out of jail. On the average, the interviews was conducted in three hours for every respondent. In order to dig and deepen what respondents think and feel, I also watch and analysis their statements in social media in particular YouTube channel. This way at once is a way to conduct triangulation for data and information about statements of the radical people and terrorists.

\section{Causes of Radicalism and Terrorism}

Some experts in many fields including social psychologists have different ideas on causes of radicalism and terrorism. They suggested that people became terrorists in many differents ways and many different puposes. In general, the experts of social sciences divided into two main perspectives in viewing causes of radicalism and 
terrorism. Some of them assumed that terror is perpetration that done by pathologist people or people who suffering from mental illness. Such this assumption believed that terrorists must be crazy and suicidal. Only someone devoid of moral feelings and beliefs could do the cold-blooded killing that a terrorist does. Some other experts assumed that the perpetrators of terror and violence on behalf on religion are people motivated by social political goals. Therefore they must be normal people who have some special plans and purposes to create their ideas and ideologies. According to them, the terrorists motivated by special ideas and ideologies to be created in reality world although theirs seemingly utopian.

First perspectives usually reffered to classic theories in psychology such as psychodynamic models or Freudian models. Almost all these classic pychological theories adhered by some psychologists saw humankinds in pesimistic point of view including about radicalism and terrorism. For example, Jerald Post a psychiatric, veteran terrorism analyst is professor of psychiatry and political psychology at George University. Earlier, he had 21 years career at the CIA serving as director of Center Analysis of Personality and Political Behavior. Dr. Post's theoretical framework is based on two components. Generational pathways to terrorism matrix which postulates that individual loyalty or disloyalty to one's parent and the nature of parent relationship to the regime are important determinant of whether individual become terrorist or normal person. It is first component, and second component postulates that terrorism is about group behavior not about individual behavior. According to Post, terrorism is also about identity in which social identity more salient than individual identity so that all services for groups, networks and his ideology are primary importance (Post, 2005).

What Jerald Post suggested about causes of terrorism was criticized by terrorism researchers today. It is because his suggestions and some others behavior scientist's using psychodynamics perspectives has been not supported by empirical studies during last two decades. All empirical studies emphasized that terrorism about normal people who have ideas and dreams to be created in reality, and they are motivated in some extent by religious teachings such as dreaming to create khilafah or Islamic states through idad and jihad in term of Muslim radicals and terrorists.

Cutting-edge studies in radicalism and terrorism revealed that ideology is most important factors that pushes people to engage in terrorist groups or acts of terror although some experts such as Marc Sagemen refused this notion (Smelser \& Mitchel, 2002). Sagemen suggested that social relations and networks are important factors in explaining why some people interested to radicalism and terrorism. In some context, what Sagemen suggested is true but in other contexts such as Islamic radical groups, attraction of the ideology is still able to explain terrorism and joining the groups. (Sagemen, 2004)

Therefore what terrorists think and feel about social world including about idad and jihad when using to deal with perceived threats of the out-groups is still needed to be discussed and elaborated. Throughout many empirical studies and direct interactions with Indonesian terrorists both inmates in the jails and formers outside the jails, I found that ideology including what they think about idad and jihad is still interesting to dig and deepen in order to know what they feel. It is very important to say since idad and jihad are central concepts in Islam particularly in fiqh of jihad.

\section{Idad and Jihad: Islamic Point of View}

Idad and jihad are Islamic concepts that found in many books of fiqh particularly that talked about how to defend Islam from enemies attacks both physically or psychologically. Idad and Jihad concepts were taken from Al-Quran and Sayings of the 
Prophet Muhammad. In this term, it must to be insisted that idad and jihad were understood in different ways among Muslims in accordance to their cognitive styles.

The word "idad" that means preparation for jihad was taken from Al-Quran (AlAnfal 8:60) and some sayings of the Prophet Muhammad that are narrated by Muslim and Abu Dawud. "Prepare your power. Remember that power is archery skill." or what Umar bin Khattab said in one occasion, "Teach your children archery skill, swimming and horseback riding." Those all became arguments for some Muslims in particular the radicals and the extremists in their Islamic understanding to prepare jihad in order for them to be strong people in dealing with different people and group showing hostile to Islam and Muslims.

Al-Quran at least mentions "jihad" repeatedly fourty times: thirteen times in past tenses, five times in present tenses, seven times in command words, four times in nouns, and four times in noun of verb (isim fi'il). Some of jihad verses were revealed in Mecca and others were revealed in Madina. Jihad verses using the word of jihad and its derivatives that revealed in Mecca generally defensive in nature. It means that all Muslim asked to be patients in dealing with enemy of Islam and Muslims, whereas those revealed in Medina commonly call Muslims to resist and opposite enemies of Islam.

Besides, sayings of the Prophet Muhammad also full of teachings about jihad.

One of his saying in Book of Shahih Bukhari as follows:

"A man asked Ibnu Masud,"What doing is most prominent?" Ibnu Masud continued his story, "So, I asked the Messenger of Allah about it, and he answered, "Praying on time." I asked again, "Anything else?" the Messenger of Allah answered, "Obeying parents" I asked again, "Anything else?" The Messenger of Allah said, "Jihad fi sabilillah"

Therefore, based on that explanation, some individual of radical Islamic groups understand jihad verses as crucial strategy in defending Islam and Muslim in on hand and other hand in opposing and resisting non-Muslims who were deemed as troubling for Islam.

Idad is a special way of certain Muslims affiliating to a radical group in dealing with social world (Moghaddam, 2006). According to them, social world is full of threats and deprivations for Islam and therefore preparation of power such as military skill is the only way to interact with threatening world. In the other hand, jihad as pivotal concepts and variable in Islamic world specifically among jihadists have strong influence toward identity both personal and social of a jihadist. Every individual of terrorist group members is proud to be jihadis and this position is guarantee for them to be honored among in-group.

Actually, jihad as part of Islamic teaching couldn't be eradicated and refused since it has been mentioned clearly in the Koran and sayings of the Prophet Muhammad. The problem regarding this concepts is when it is understood literally and restricted to special meaning mainly physical fighting again Islam enemies and whoever hostile to Muslims.

In this term, all Muslim clerics agreed that jihad has not merely one meaning but it has many meanings from soft meaning to hard meaning. Some clerics said that jihad must be understood under special contexts and conditions. In other word, in order to apply jihad in this time every individual and group must put it in its context and meet some conditions of time and place. Putting jihad in its context and making effort to meet its conditions are something likely to be violated by those who claim their selves as jihadists (Gazi, 2016). 


\section{Idad and Jihad As Tool in Dealing with Outgroup Threats}

Based on some interviews with terrorism inmates and former terrorism inmates inside jails and outside jails I have conducted for many years, it was found that idad and jihad are two words that have been strongly known. These words very familiar among radical Muslim and certainly Indonesian terrorists both inmates in the jail and former inmates in our surroundings.

According to them, idad is strategic way for Muslims to deal with infidel people who always threat Islam through different ways and tools. This idad must be done by every Muslims with special ways they can choose. In general, the radical Muslims and terrorism inmates choose quasi-military training since it is deemed as appropriate way although it violate law of Indonesia.

One terrorist inmate whom I visited in the jail said, "According to us the jihadists, idad is one of some ways that we can take in dealing with threats surrounding Islam and Muslims. You know, Al-Quran and Hadis have commanded us to prepare ourselves with many skills such as archery, swimming, and horseback riding. This idad must be done by every Muslin since it is very important in this era in which Muslims become hostile target of all infidel people"

Most of terrorism inmates believe that infidel people will never accept Muslims as ummah that united in one belief in God. The infidel people will never ending their efforts to stop Muslim in gaining a success in every field of life. Therefore according to terrorism inmate I interview, all Muslims individually and collectively have to prepare their selves to enter jihad era physically and cognitively.

One terrorist inmate I visited in Semarang jail expressed his feeling clearly: "You know brother, we are facing hostility from all infidel people everywhere. Therefore, our task is to prepare our selves to jihad.. You know idad concept as mentioned in our Holy Book and Sayings of our Prophet? Idad has purpose to make infidel people fear of Islam..."

Eventually, as mentioned in terrorism literatures, the most important thing to know related to act of terror is why do terrorists choose jihad? Answer of this question will uncover what they think behind jihad that they misunderstood about it. According to interview I conducted in some jails, it was found that they choose jihad that they interpreted in wrong way because their imagination about rewards in hereafter life such as staying in paradise and marrying beautiful angels through death or what they called it as "istisyhad"

One terrorism inmate, a young Muslims of ISIS fan who is under arrest because of his effort to travel to Suriah said, "I always ask, why do polices inhibit and forbid us to leave Indonesia and to join ISIS? Actually it is our right to get "syahadah".You know brother, "istisyhad" is my goal and I will be happy if die in a state of jihad. It was my intention since long time ago.. Why you inhibit us? Why do you stop us to get our happiness. to live in paradise and to get beautiful angels? You have to know it is my right.. Understand?"

\section{Conclusion}

On the basis of preverious parts of this article, it was concluded that Indonesian terrorists in particular those who were chosen as respondents or subjects of the study perceived and understood jihad as legitimate tool for defending Islam and Muslims in one hand and for defeating all enemies of Islam and Muslims in other hand.

Most of what the Indonesian terrorists understood and believed about idad and jihad often describes feeling of threatened particularly that related to their collective 
identity as Muslims. In their opinion, imagined threats that they perceived must oppose with physical semi-military training.

Finally, the Indonesian radical Muslims and terrorists choose jihad as tool in dealing with imagined threats from whom they deem as infidel people or "thogut" because of their incapability to compete and race against out-groups. Therefore they leave real competition and rally and move to something imagined and it is hereafter life through jihad. Because through it, they will get rewards in hereafter life including to stay in paradise and marry the beautiful angels.

\section{References}

Baumeister, R. F., \& Finkel, E. J. 2010. Advanced Social Psychology: The State of The Science. New York: Oxford University Press.

Borum, R. 2008. Psychology of terrorism. Florida: University of Florida Press.

Brewer, M. B. 2010. Intergroup relations. Dalam R. F. Baumester, \& E. J. Finkel, Advanced Social Psychology. New York: Oxford University Press.

Brown, R., \& Gaertner, S. 2003. Handbook of Psychology: Intergroup Processes. Malden MA: Blackwell Publishing.

Cronin, A. K. 2009. How terroris campaign end. Dalam T. Bjorgo, \& J. Horgan, Leaving Terrorist Behind: Individual and Collective Disengagement (hal. 49-65). New York: Routledge.

Eileen, H., \& Blakar, R. M. 2012. Ideology and Social Psychology. Social and Personality Psychology Compass 6/4, 282-294. 10.1111/j.17519004.2012.00428.x.

Gazi. 2016. Dinamika Relasi Sosial Dalam Proses Meninggalkan Jalan Teror. Disertasi belum diterbitkan. Depok: Program Doktor Psikologi Universitas Indonesia.

Merari, A. 2007. Psychological aspects of suicide terrorism. Dalam B. Bongar, L. M. Brown, L. E. Beutler, J. N. Breckenridge, \& P. G. Zimbardo, The Psychology of Terrorism (hal. 101-115). Oxford: Oxford University Press.

Moghaddam, F. M. 2006. From the terrorists' point of view: what they experience and why they come to destroy. London: Praeger Security International .

Post, J. 2005. Addressing the causes of terrorism: Psychology. The International Summit on Democracy, Terrorism, and Security (hal. 7-12). Madrid: Club De Madrid.

Postmes, T., \& Jetten, J. 2006. Individuality and the Group: Advances in Social Identity. London: Sage Publication.

Sagemen, M. 2004. Understanding terror network. Philadelphia, Pennsylvania: University of Pennsylvania Press.

Saloom, G. 2015. Identiifikasi kolektif dan ideologisasi jihadi: Studi kualitatif teroris di Indonesia. Dialog. Jurnal Penelitian dan Kajian Keagamaan Vol. 38 No. 1 Juni 2015, 1-12.

Smelser, N. J., \& Mitchel, F. 2002. Terrorism: Perspectives from the behavioral and social sciences. Washington DC: The National Academic Press.

Victoroff, J., \& Kruglanski, A. W. 2009. Psychology of Terrorism. New York: Psychology Press. 